\title{
Ármin Vámbéry (1832-1913) as a Historian of Early Hungarian Settlement in the Carpathian Basin
}

\section{Nándor Dreisziger}

\begin{abstract}
In the English-speaking world Ármin Vámbéry is known as a traveler in Central Asia and a student of Turkic cultures and languages. In his native Hungary he is also known for his disagreement with linguists who believed that Hungarian belonged to the Ugric branch of the Finno-Ugric languages - a part of the Uralic linguistic family. Rather than accepting this theory, Vámbéry contended that Hungarian was largely a Turkic language that belonged more to the Altaic family. Few people know that Vámbéry also expressed strong opinions about the genesis of the Hungarian nation. The most important aspect of Vámbéry's theory about Hungarian origins is the thesis that Hungarian ethnogenesis took place - beginning with late Roman times or even earlier-in the Carpathian Basin. A corollary of this proposition is that the nomadic tribes that conquered the Carpathian Basin at the end of the ninth century were Turkic peoples who were few in numbers and were assimilated by the region's autochthonous - and by then Hungarianspeaking — population. This paper outlines Vámbéry's arguments and describes to what extent research on this subject in the century since Vámbéry's death has confirmed or contradicted his unconventional ideas.
\end{abstract}

Keywords: Ármin Vámbéry, Hungarian ethnogenesis, Hungarian origins, Hungarian conquest, Hungarian historiography

Biography: From 1970 to 2008 Nándor Dreisziger taught history at the Royal Military College of Canada. He has published widely on North American and East European subjects. Since 1974 he has been editing the Hungarian Studies Review. His most recent field of interest is Hungarian ethnogenesis.

\section{Introduction}

Throughout his life, Ármin Vámbéry held strong opinions regarding almost everything, and was not reluctant to voice these, often in several languages. Few people know, however, that he had come to unusual conclusions about Hungarian ethnogenesis too, especially regarding the settlement of the Hungarians' ancestors in the Carpathian Basin. In this study I plan to describe Vámbéry's opinions about this subject, especially as they were outlined in a posthumously published book of his: A magyarság bölcsőjénél: A magyar-török rokonság kezdete és fejlödése 
Dreisziger, Nándor. "Ármin Vámbéry (1832-1913) as a Historian of Early Hungarian Settlement in the Carpathian Basin." Hungarian Cultural Studies. e-Journal of the American Hungarian Educators Association, Volume 6 (2013): http://ahea.pitt.edu DOI: 10.5195/ahea.2013.110

[At the cradle of Hungarians: The beginning and development of the Magyar-Turkish relatedness] (Budapest: Athenaeum, 1914). In the second half of my essay I will describe how Vámbéry's theories played out in the one-hundred years since his death, with an emphasis on the views of scholars who had come to similar conclusions. I will bring my paper to an end with a few comments relating to the evidence that the sciences of genetics and physical anthropology have brought to this subject. My overall conclusions will probably surprise most members of Hungary's historical establishment. The evidence that historical research in Hungary has brought to this subject over the last hundred years, and the light that has been thrown on it by genetic and anthropological studies, suggest that Vámbéry's very unconventional views about Hungarian ethnogenesis deserve far more — and more careful — attention than they have received in Hungarian scholarly circles to date.

\section{The Life of Hermann Wamberger}

Few people who achieved fame and social eminence in life were born in more adverse circumstances than Vámbéry, who hailed from an impoverished Jewish family. Typical of his lowly social and economic status is the fact that posterity is not certain in what year he was born (1831 or 1832), where he was born (in Szentgyörgy [today's Svätý Jur in Slovakia] or in Dunaszerdahely [today's Dunajská Streda, also in Slovakia]) and even the spelling of his original name: Wamberger, but according to some scholars, Bamberger. That his early life was not auspicious is an understatement. Before Hermann (as he was originally called) became a toddler his father died, and about two years later he was struck by an ailment that would leave him with a limp for the rest of his life. By the time he was of school age his mother re-married and the family moved from Szentgyörgy to Dunaszerdahely. Here in the midst of great poverty Hermann began his schooling (Mandler 2011, 47-58). ${ }^{1}$

What saved the future Ármin Vámbéry from living a life in obscurity was his knack for learning languages. Although at one point he had to leave school and become a tailor's assistant, and then a language tutor to a member of the village elite, the fact that by the age of sixteen he had command of half-dozen languages gained him sponsors who were willing to help finance his education. In the late 1840s he was studying in a Lutheran secondary school in Sopron, then in Pozsony (today's Bratislava, in Slovakia), and finally in a Piarist school in Pest. In the meantime he kept tutoring to earn some money. By this time he was also studying English as well as some Scandinavian and Slavic languages. Next he became interested in Turkish literature and began learning the language itself. In the meantime he became acquainted with several of Hungary's prominent academics as well as literary figures, including the noted poet János Arany (Kocsis 2013). ${ }^{2}$

\footnotetext{
${ }^{1}$ Mandler tells how Hermann's mother's aspirations for him to become a medical doctor resulted in his transfer from a Jewish school to a Protestant school-much to the displeasure of members of the local Jewish community (49).

${ }^{2}$ According to Károly Kocsis, the director of Hungary's Institute of Geography, the seven languages the young Hermann knew were Magyar, Hebrew, Latin, Slovak, French and Italian, in addition to his native German (Hermann's mother's mother-tongue was German).
} 
Dreisziger, Nándor. "Ármin Vámbéry (1832-1913) as a Historian of Early Hungarian Settlement in the Carpathian Basin." Hungarian Cultural Studies. e-Journal of the American Hungarian Educators Association, Volume 6 (2013): http://ahea.pitt.edu DOI: 10.5195/ahea.2013.110

In 1857 Vámbéry departed for Istanbul with the financial support of Baron József Eötvös. While there he honed his linguistic skills and made acquaintances with prominent members of the city's elite. He did historical research and compiled an English-Turkish dictionary. Through his contacts he managed to get hold of the Ottoman-Turkish translation of a medieval Hungarian chronicle the Tarih-i üngürüs, which he took back with him to Hungary. We can suspect that his interest in the Hungarian past intensified at this time. ${ }^{3}$

In 1861 Vámbéry retuned to Pest only to prepare for a grand tour of Central Asia. The purported purpose of the tour was to find the ancient homeland of the Hungarians. He completed much of the tour in the guise of a mendicant Sunni dervish named Resid Effendi, returning to Hungary in the spring of 1864. The following year he travelled to England where he gave accounts of his travels and published the book Travels in Central Asia. The same year he got an appointment at Budapest's Catholic University teaching Oriental languages. Soon he became involved in a bitter and prolonged debate with other academics about the nature of the Hungarian language by arguing that it was mainly Turkic - his opponents insisted that it was predominantly Finno-Ugric. The last four decades of his life brought him more Hungarian and international distinctions and saw him publishing more books, mostly about his travels but also about Hungarian ethnogenesis. The accolades he received included full membership in the Hungarian Academy of Sciences as well as being elected as president of the Hungarian Geographical Society from 1898 to 1890.

Hardly any writer who has dealt with Vámbéry's life and scholarship has focused on his explanations of Hungarian ethnogenesis. The main purpose of our present inquiry is to fill this gap in the literature. Because of limitations of space, I will concentrate on his very last book related to this subject. In any case, his earlier monographs, and especially the one he published in 1895 for the millennial celebrations of the arrival of Prince Árpád's tribes in the Carpathian Basin, contained many of the same arguments as his last book: 1) Hungarians have a very complex family tree; 2) similarities between languages do not necessarily imply blood relationship between the peoples who speak them; 3) the Magyar language was the product of the merger of an ancient Ugric tongue with east-Turkic dialects; 4) the Magyar nation emerged from a melting-together of various peoples coming from the east, and 5) the cauldron of this ethnogenesis had been the Carpathian Basin — long before the arrival of Prince Árpád and his warriors. ${ }^{4}$

\footnotetext{
${ }^{3}$ Tarih-i üngürüs is a controversial chronicle. Its original has been lost. What exists is a translation of it written in the Ottoman Turkish language, and penned in Arabic script. To what extent its re-translation into Hungarian resembles the original text is a matter of conjecture.

${ }^{4}$ When he wrote the first of his books about Hungarian ethnogenesis, Vámbéry was still imbued with his "discovery" of the "Turkic origin" of Hungarians. At this time he argued that the kernel of the Magyar language was Turkic, an argument that he would reverse by the time of the writing of his second book on Hungarian origins. In this new work he admitted that the core of the Magyar tongue was "Ugric" but maintained that much of the language (both vocabulary and grammar) was Turkic. Vámbéry’s first book on the subject was called A magyarok eredete [The origin of Hungarians] (Budapest, 1882) and his second book was entitled A magyarság keletkezése és gyarapodása [The genesis and development of Hungarians] (Budapest: Franklin, 1895, republished in Dunaszerdahely, 2003); for an internet version see http://mek.oszk.hu/03000/03032/.
} 
Dreisziger, Nándor. "Ármin Vámbéry (1832-1913) as a Historian of Early Hungarian Settlement in the Carpathian Basin." Hungarian Cultural Studies. e-Journal of the American Hungarian Educators Association, Volume 6 (2013): http://ahea.pitt.edu DOI: 10.5195/ahea.2013.110

\section{Vámbéry's Book: At the Cradle of Hungarians}

The best reason for focusing on Vámbéry's last book relating to Hungarian ethnogenesis is that in this work he goes into the specifics more than in his previous monographs. Since the examination of all of Vámbéry's ideas on the subject would require more of a book than a scholarly article, this inquiry will deal only with a few essential elements of his theories.

Vámbéry began his 1914 book by reflecting on his previous two volumes on the subject. He tells his readers that the purpose of his first book had been to counter-balance the undue emphasis in the writings of Hungary's academics on the Hungarians' Finno-Ugric origins. Accordingly, in his 1882 work he stressed the diverse origins of the Hungarian language and explained that while even in ancient times Hungarians were a mixture of Finno-Ugric and Turkic-Tatar ethnic elements, in subsequent times they had become even more Turkic linguistically, culturally and politically. The aim of writing his second book, according to Vámbéry, was to augment and rectify patriotic and romantic public perceptions in Hungary about Magyar ethnogenesis with new knowledge about Ural-Altaic languages and peoples. He bemoaned the fact that his 1895 description of ancient Hungarians as a people of highly mixed origins had not been well received by Hungary's reading public, and argued that national pride and belief in a romanticised past should not be a part of a nation's image of its origins. All nations are of mixed origins, Vámbéry argued, and Hungarians are especially so given the fact that their genesis had taken place in the borderlands of Asia and Europe. Since Hungarians are of mixed ethnic origins it follows that their language is also the product of the intermingling of many tongues. Lacking a pure language that could guide linguists to reconstruct the national past, Hungarians have a very difficult task in getting to know their ethnogenesis. Because Hungarian is a language of highly mixed origins, it lends itself to diverse interpretation of the Magyar past (Vámbéry 1914, 5-11).

In the second chapter of his 1914 book Vámbéry admits that, as far as the grammatical structure of the Hungarian language is concerned, the Ugric elements are predominant over "Turkic-Tatar" structural elements. He concludes that this situation is not surprising since the Ugric languages are much older than the Turkic ones; in fact, "the linguistic remnants" of the Ural-Altaic languages in Hungarian are undoubtedly some of the "oldest linguistic remnants" in the world. Having said all that, Vámbéry proceeds to argue that the two languages, Turkish and Magyar, and especially their diction, are so closely related to each other that their relatedness cannot be explained by the exchange of loan-words, but only by an "inner melting-together" [belsö összeolvadás] and "thoroughgoing intermingling" [mélyreható keveredés]. When you have a language, Vámbéry argued, that is "two-thirds" Turkic and "hardly one-third" Ugric, you cannot explain its true nature simply by references to word borrowing (Vámbéry 1914, 12-13, 19-20 and 29).

In the next chapter of his book Vámbéry turns to the question of the timing and place of this linguistic intermingling. In connection with the question of timing Vámbéry observes that the Ugric elements of the Hungarian language-which exist in the language of other Ugric peoples also - could only come from an age when these peoples had not separated 
Dreisziger, Nándor. "Ármin Vámbéry (1832-1913) as a Historian of Early Hungarian Settlement in the Carpathian Basin." Hungarian Cultural Studies. e-Journal of the American Hungarian Educators Association, Volume 6 (2013): http://ahea.pitt.edu DOI: 10.5195/ahea.2013.110

from each other. In the absence of documentary and other evidence the timing of this separation cannot be established even approximately, but Vámbéry is ready to say that the "birth of the Hungarian people and language" had taken place in a "much earlier age" than Hungarian scholars had estimated (Vámbéry 1914, 53-54).

As to the question where and under what circumstances the mixing of the Ugric and Turkic languages had taken place, Vámbéry admitted that answers are difficult to provide. Arabic or Byzantine sources provide no information regarding the subject; however, there are other circumstances that give a clue. The most important of these is that the mixing of languages is more likely to happen in settled, or at least semi-nomadic, societies than in entirely nomadic societies. In this connection he observes that the Uralic-Altaic peoples who throughout the age of migrations had moved from Inner Asia to the West had all been nomadic societies. Such societies were those of the Huns and the Avars-who, according to the sources Vámbéry had found, have to be definitely considered Altaic, i.e. Turkic-speakers. Linguistic mixing between such peoples and Ugric tribes could not have taken place before they arrived and settled down in the Carpathian Basin. Intermixing between such "ethnic fragments" [néptöredékek] could only have taken place there. Another component of the language that emerged as the result of this "melting-together" came from a Slavic language. The source of this particular linguistic admixture was the language of the South Slavs of the old Roman province of Pannonia. After they had contributed to the emerging language of the Hungarians, these Slovenians were "squeezed out" of that region by the Franks and Northern Slavic newcomers. According to Vámbéry, the language that emerged from this intermixing of diverse Ugric, Turkic and South Slav tongues must have been born long before the end of the ninth century (Vámbéry 1914, 54$60)$.

Next, Vámbéry explains how this process of the Hungarian language's genesis might have taken place. First of all, in the society in which this happened, the Turkic element must have held the political, social and military power - that is, Turks must have ruled over fragments of the Ugric and other ethnic groups living in the Carpathian Basin. Secondly, it has to be kept in mind that the immigration there of various tribes and tribal factions must have taken place in various stages, i.e. at various intervals. These migrants joined the population that had survived there after the collapse of the Roman Empire in the West and had lived their tranquil livesuntil, under a leader such as the "[Avar kahn] Baján," they began playing a prominent role on the stage of world history.

At the end of the ninth century a new development took place in the Carpathian Basin: the people that later became known as the Magyars arrived. Vámbéry estimates the numbers of the new arrivals as being "a few thousand" [néhány ezer], and he has no doubt that these Turkish-Tatar warriors melted into the mass of local peoples. In doing so, Vámbéry explains, they exchanged their "pure Turkish language" for the "mixed language" of their Pannonian "relatives." Though the new arrivals were few, their "militaristic spirit", characteristic of their not yet adulterated nomadic lifestyle, inspired the Carpathian Basin's post-Avar population to rise to remarkable deeds again as exemplified by their military expeditions far and wide in Europe. Furthermore, according to Vámbéry, the union of these two peoples had longterm benefits for the newly arrived conquerors as well. Through this union they began losing 
Dreisziger, Nándor. "Ármin Vámbéry (1832-1913) as a Historian of Early Hungarian Settlement in the Carpathian Basin." Hungarian Cultural Studies. e-Journal of the American Hungarian Educators Association, Volume 6 (2013): http://ahea.pitt.edu DOI: 10.5195/ahea.2013.110

their nomadic traditions and, as a result, they found accepting the ways of Western European society easier. Last but not least, according to Vámbéry, the new nation that emerged through this union of the conquerors and the local population became known by the name of the former: Magyar. (Vámbéry 1914, 59-65)

The military expeditions abroad could not continue indefinitely and the political entity established as the result of the so-called "Hungarian conquest" had to undergo a fundamental transformation: its people had to convert to Christianity. The process of conversion, according to Vámbéry, was made easier by the fact that the autochthonous element of the population was to some extent familiar with Christian teachings. Vámbéry explains that this process of the abandoning of nomadism and accepting Christianity was not easy for the newly arrived conquerors and some of them even staged uprisings against the changes being imposed on them by Hungary's rulers. All this is little known, as historical sources do not say much about the conquerors. There is some information on them in Byzantine documents but most of this is unreliable: not even the name of their leader is known: the noun árpád in some Turkic languages means the one who is noble or the one who leads. There is one exception to all this: in calling the conquerors of the Carpathian Basin Turks, according to Vámbéry, the Byzantines were correct. As to the conquered population of the Carpathian Basin, Vámbéry claims that written sources say nothing about them (Vámbéry 1914, 66-82). ${ }^{5}$

As far as the chronology of Turkic languages is concerned, Vámbéry distinguished three varieties, each of which was known to Turkologists by a limited number of written relics. The first of the three varieties were the eastern Turkic tongues of the fourth to seventh centuries (or even earlier). Into the second group belonged the western Turkish tongues; their relics date from the early fourteenth to the mid-fifteenth centuries. And then there was modern Osmali, whose written sources date from the mid-fifteenth century on. In its structure and diction the Hungarian language, according to Vámbéry, pre-dates all the known Turkic relics. In other words, the vocabulary of all three varieties of Turkic can be found in the Magyar language. This circumstance suggests to Vámbéry that the intermixing or genesis of the Hungarian ancestors' Ugric and Turkic conglomerate language took place during or even before the fifth century. This was the time of the birth of the Hungarian language, and also of the rise of the ancient Hungarian belief in the two conquests of the Carpathian Basin: the first by Attila the Hun and the second by Árpád the leader of the Magyars (Vámbéry 1914, 89-93).

Of the three varieties of Turkic, according to Vámbéry, the Magyar language was impacted most by the ancient, eastern branch. Nomadic tribes and tribal factions speaking these tongues had been arriving in the Carpathian Basin periodically and their vocabulary had entered the language being in the process of being formed there. Later arrivals, speaking west-Turkic languages, also had an impact on this language. These peoples "stepped on the stage of world history" only after the Ugric-Turkish language of the ancient Hungarians had developed [megalakult] (Vámbéry 1914, 93-97).

\footnotetext{
${ }^{5}$ As to the origins of the name Magyar, Vámbéry opines that it came from Volga-Turkic and its original form was majar (meaning my lord). With the Turks the "j" [in English "y" as in the word "yard"] mutated to the hard dzs sound - and with Ugric-speakers to the soft "gy" as in Magyar.
} 
Dreisziger, Nándor. "Ármin Vámbéry (1832-1913) as a Historian of Early Hungarian Settlement in the Carpathian Basin." Hungarian Cultural Studies. e-Journal of the American Hungarian Educators Association, Volume 6 (2013): http://ahea.pitt.edu DOI: 10.5195/ahea.2013.110

In chapter XII Vámbéry returns to the theme of the Hungarian language's genesis from its Ugric and Turkic components. Here he reaffirms his belief that the kernel [mag] of this amalgam language came from its Ugric element, but argues that the Turkic element had joined this original constituent quite early and continued to exercise its influence on it for centuries. All this transpired in the Carpathian Basin. The people who spoke this amalgam language were variously called by their neighbours Huns, Ungars, Avars, Turks and Magyars. After the disintegration of the Hun Empire they lived their lives in a relatively tranquil [zavartalan] way. Western Europeans knew nothing about their activities, although in the times of Baján the Avar, for example, they caused a lot of problems for the Byzantines. In the meantime, nomadic peoples continued to arrive from the east. The Turks who came at the end of the ninth century constituted the most important and most powerful of these and they gave the peoples of the Carpathian Basin “final political form” [végleges politikai alakot] (Vámbéry 1914, 99-103).

Here Vámbéry re-asserts his earlier claim that the conquerors of the late ninth century were very few in number [nagyon kevesen voltak], but they were warlike and gave courage and inspiration to the people of the Carpathian Basin who had been struggling against enemies, especially the Franks, and soon they conducted military incursions far into the lands of other, mainly Christian European, peoples. As far as language and a way of life were concerned, the newcomers soon joined [hamarosan csatlakoztak] the local majority and "melted into" the already part-Christian world of this "large Uralic-Altaic conglomerate" (Vámbéry 1914, 104106).

Vámbéry begins chapter XV of his book by saying that, after having demonstrated the heterogeneous nature of the Hungarian population in early medieval times, as well as the fact that at the time Ural-Altaic tribal elements were arriving in the Carpathian Basin repeatedly and incessantly [szakadatlaul], he can turn to the subject of what word-of-mouth evidence remained of these processes in folk memory. The first of such evidence should pertain to the Huns, which is fine with Vámbéry who is convinced that the ethnic group that had come about as the result of the merger of Ugric and Turkic elements had already existed in the Carpathian Basin in the fourth century or "perhaps earlier" - that is before the Huns' arrival and also before the Slavs began to settle in the valleys of Pannonia (Vámbéry 1914, 117-118).

In connection with the Slavs, Vámbéry digresses and takes time to refute the accusation by contemporary Slav publicists that "Árpád's Hungarians" had wedged themselves between North and South Slavs and forever separated them. Hungarians, the speakers of an Ugric-Turkic language, were there before the Slavs, and Árpád's people were a "Turkish ethnic group" [török néptörzs] that later "completely melted into" [egészen beolvadt] the local population - so the accusation made by Slavic propagandists is fallacious. Notwithstanding the fact that the new arrivals became assimilated, they and their descendants became the Carpathian Basin's new military and political masters, thereby replacing the remnants of the Hun, Avar and other previous ruling elites - and they maintained their supremacy through the subsequent centuries of turbulence and struggles (Vámbéry 1914, 118-119). Returning to the oral evidence regarding the age, Vámbéry argues that everything posterity knows about the subject comes from foreign sources, and is unreliable. Even the Hungarian chroniclers of a later age relied on nonHungarian sources and gave false accounts of the deeds of the Hungarians. None of these chroniclers, in Vámbéry's opinion, knew the country's peoples, their traditions and the languages they spoke. The result was that posterity has very little to guide it regarding the Hungarian past (Vámbéry 1914, 119-123). 
Dreisziger, Nándor. "Ármin Vámbéry (1832-1913) as a Historian of Early Hungarian Settlement in the Carpathian Basin." Hungarian Cultural Studies. e-Journal of the American Hungarian Educators Association, Volume 6 (2013): http://ahea.pitt.edu DOI: 10.5195/ahea.2013.110

Chapter XVI constitutes Vámbéry’s conclusions. In this chapter he first asked that, if written sources regarding the Hungarian past hardly exist, and those that do exist are unreliable, then where can Hungarians find reliable information about their origins? His answer was unequivocal: from linguistics, especially from the Magyar tongue's Turkic legacy (Vámbéry 1914, 123-127).

\section{Unconventional Opinions about Hungarian Origins since 1913}

In his work on Hungarian ethnogenesis, and especially in his 1914 posthumous book, Vámbéry offered a radically new interpretation of the early history of Hungarians. He gave a new explanation as to when, where, and how the people that later became the "Magyar nation" had arisen. By doing so he challenged his country's academic establishment to confirm or refute his theories. One hundred years later, Vámbéry's ideas continue to pose a challenge to Hungary's academic establishment. His bold interpretations have not really been refuted —or confirmedcompletely. Perhaps some of Vámbéry's colleagues felt that he was part of a lunatic fringe of pseudo-intellectuals and his books were not worth reading, while others held that he was so far out on a limb that debating his theories was unnecessary. Whatever happened, in today's Hungary the old explanation of Hungarian ethnogenesis, arguing that the conquerors who occupied the Carpathian Basin at the end of the ninth century had brought the Hungarian language there and that they are the ancestors of modern-day Hungarians, still reigns virtually unchallenged.

While in the years immediately after Vámbéry's death no one stood up and defended his theories concerning the early history of Hungarians, in the century since several Hungarian academics came along and espoused similar and equally radical interpretations of Magyar origins. The first of these who merits mention was Lajos Kiss of Marjalak (in Hungarian: Marjalaki Kiss Lajos, 1887-1972). Like Vámbéry, or even more so, he is very much a forgotten scholar in today's Hungary. Also like Vámbéry, he had a disadvantaged family background: he was born in 1887 into a poor peasant family. Despite the poverty that surrounded him in childhood, Marjalaki, alone among his numerous siblings, managed to get an education. From 1910 to 1913 he attended university in Budapest and graduated in geography and history. Subsequently, he published several articles and textbooks, and in 1923 participated in an archaeological dig near the village of Mezőnyék in northern Hungary. He continued to publish thereafter and to correspond with many of Hungary's noted intellectuals.

The most important essay Marjalaki produced appeared in the periodical Nyugat [West] in 1930. In this article he gave the conclusions that he had come to after examining the writings of the chronicler Anonymus. Parts of his essay are worth quoting:

At the time of [Prince] Árpád's [arrival] the land [that later became] Hungary was a densely populated place. The regions of this beautiful and fertile land... were inhabited by a Hungarian-speaking... settled people. These peaceful fishers, tenders of animals and tillers of the soil, during the millennium before the Hungarian conquest... had changed masters so many times that they never even thought of resisting Árpád and his conquerors. Their masters of the time were not of their people, and [the struggle for their land] was not their business but that of the people who ruled them....(Marjalaki 1930) 
Dreisziger, Nándor. "Ármin Vámbéry (1832-1913) as a Historian of Early Hungarian Settlement in the Carpathian Basin." Hungarian Cultural Studies. e-Journal of the American Hungarian Educators Association, Volume 6 (2013): http://ahea.pitt.edu DOI: 10.5195/ahea.2013.110

Marjalaki outlined his interpretation of the "Hungarian conquest" in point form as well: 1) the Carpathian Basin at the time of the Conquest was not a sparsely populated place; 2) the conquering tribes did not exterminate the peoples they found, they subjugated them; 3) with the arrival of the conquerors the subjugated autochthonous [öslakós] inhabitants just exchanged one ruling elite for another; 4) when describing the people who lived in the eastern two-thirds of the Carpathian Basin at the time of the Conquest, Anonymus does not talk about Slavs or other ethnic groups, only the "inhabitants of the land" (what language these "inhabitants" used, can easily be established from the geographical names Anonymus used: the vast majority of which are undoubtedly Hungarian, especially the names of rivers); 5) nowhere in his work did Anonymus say that the conquerors brought tillers of the soil with them, but in at least two dozen places he mentions the fact that Árpád, in his generosity, gave this or that among his followers a tract of land as reward, "together with its numerous subject inhabitants"; 6) at the time of Árpád's conquest, a large majority of the Carpathian Basin's population, especially east of the line of the Danube and Garam rivers, couldn't have been other than Hungarian; 7) judging by their personal names, the members of Árpád's conquering army must have been Turkic — this Turkic element of the Carpathian Basin's popuation was reinforced later by the arrival of Pecheneg, Kun, etc. populations, but they were all gradually and imperceptibly assimilated by the masses of Magyar-speaking peasants; 8) Anonymus refers many times to the fact that the peasants of the times spoke a different language than the conquerors; 9) among the rivers mentioned by Anonymus, there is not one that has been proven to have had another name prior to the Conquest (Marjalaki, 1930 and 1956).

Although Marjalaki did not offer an explanation as to how the Hungarian people had evolved before the ninth century, he agreed with much of what Vámbéry said about Hungarian ethnogenesis. The fact that both of these scholars had come from the lower rungs of Hungarian society is significant. The members of Hungary's social elite of the times considered themselves descendants of Árpád's people and were less likely to question the role these purported "ancestors" played in Hungarian ethnogenesis. Apparently the task of questioning the orthodox explanations was left to social outcasts such as Vámbéry and Marjalaki-not surprisingly they were both ignored. The next two critics of historical orthodoxy received somewhat more attention.

\section{The "Dual Conquest" Theory of Gyula László and János Makkay}

By the mid-twentieth century a new critic of historical orthodoxy had emerged. He was Gyula László who, through his indefatigable work, would become the best-known among the scholars who questioned the old story of Hungarian origins. There is even a school named after him: the "Dual Conquest" [kettös honfoglalás] theory. This is a hypothesis that has caused much confusion among Hungary's academic and lay reading public - a confusion that persists to this very day.

Gyula László was born in Köhalom, Transylvania (in today’s Braşov County, in Romania), in 1910. He completed his elementary and secondary schooling there, in Kolozsvár (today's Cluj in Romania), and in Budapest. In his university years, which he also spent in Budapest, he studied art, art history, ethnography, geography and archaeology. He began his career being employed by various museums and later became the head of the Medieval Department of Hungary's National Museum. His travels and researches took him to England, Italy, France and Greece. Throughout much of the 1940s he taught at the University of 
Dreisziger, Nándor. "Ármin Vámbéry (1832-1913) as a Historian of Early Hungarian Settlement in the Carpathian Basin." Hungarian Cultural Studies. e-Journal of the American Hungarian Educators Association, Volume 6 (2013): http://ahea.pitt.edu DOI: 10.5195/ahea.2013.110

Kolozsvár and also produced many art works - including paintings, drawings, and sculptures. In the early 1950s he once again worked for the National Museum in Budapest and in 1957 joined the faculty of Eötvös Loránd University in Budapest where he taught archaeology until his retirement in 1980. Starting with the 1940s, he was involved in numerous archaeological investigations, especially in his native Transylvania.

László's examination of seventh to tenth century graveyards led him to a new interpretation of Hungarian ethnogenesis. The evidence he found, rather than reinforcing in him the idea that the ancestors of Hungarians arrived in the Carpathian Basin at the end of the ninth century, suggested to him that the majority of them must have settled there much earlier, mostly during the Avar era of Central European history, probably in the 670s. Linguistic evidence, produced by Laszló's contemporaries, told him the same thing (László 1978). He remarked in an interview he gave towards the end of his life that 90 to 95 percent of the personal names of the elite in post-conquest Hungary was Turkic, while among the subject population, 90 to 95 percent of the people had Hungarian names. Another circumstance that reinforced his new interpretation of the "Hungarian conquest" was the fact that his exploration of contemporary graves and cemeteries told him that the subject peoples of tenth century Hungary outnumbered to a large degree the newly-arrived conquerors. The ancestors of the Hungarians lived in large villages and their cemeteries contained the remains of thousands, while in the same cemeteries the graves of the newly arrived numbered only a few dozen. "When 20 members of the elite lived among 2,000 of their subjects, who assimilated whom?" he asked. Not surprisingly László amended his theory. Whereas originally he had argued that the ancestors of the Hungarians arrived in the Carpathian Basin in two waves, in the 670s and in the 890s, now he declared that the vast majority of them came with the first conquest, and that the people responsible for the second were predominantly Turks (László 1997).

László tried to publicise his new, amended theory until the very end of his life saying that he didn't mind if his name was forgotten as long as his ideas survived. He died in 1998 while he was on another lecture tour of the towns and cities of his native Transylvania. After his death the task of defending his theory, especially as it was amended in the mid-1990s, became the lot of one of his disciples, the much younger János Makkay.

Makkay graduated from Eötvös Loránd University in 1957. Subsequently, he found employment in various museums and finally with the Institute of Archaeology of the Hungarian Academy of Sciences. After 2002, for a few years he was a member of the faculty of the University of Pécs. His early work concentrated on European pre-history but later he began focusing on the archaeology of the Carpathian Basin and Hungarian ethnogenesis. One of his early publications in defense of the dual conquest theory appeared in Hungary's leading anthropological journal in 1993 (Makkay 1993, 213-219). A much more detailed work regarding the subject was his monograph, A magyarság keltezése [The dating of Hungarians]. In this work Makkay used evidence produced by historians, linguists, anthropologists and scholars in other disciplines to support László's arguments. Concerning linguistic evidence, Makkay argued that the Bulgaro-Turkic loan words that exist in the Magyar language were borrowed not during the Hungarians' supposed centuries-long travels through the steppe-lands north of the Black Sea, as the proponents of the dominant theory of Hungarian ethnogenesis suggest, but were acquired while Hungarians had lived along with various Bulgar tribes or tribal fragments (as well as other Turkic peoples) in the Carpathian Basin in the centuries before 895. And the same was true, 
Dreisziger, Nándor. "Ármin Vámbéry (1832-1913) as a Historian of Early Hungarian Settlement in the Carpathian Basin." Hungarian Cultural Studies. e-Journal of the American Hungarian Educators Association, Volume 6 (2013): http://ahea.pitt.edu DOI: 10.5195/ahea.2013.110

according to Makkay, of Slavic loan-words in Hungarian: these were acquired by Magyar agriculturalists who had co-habited with Slavic settlers for centuries in the Carpathian Basinlong before the "Hungarian conquest".

Makkay pointed out that many words in Hungarian describing organized religion are of South Slavic origin. According to him, these words entered the Magyar language in the Carpathian Basin as the result of the interaction over many generations of the Hungarians with Christian Slavs there. Had Hungarians not been living in the Carpathian Basin at that time but only after 895 , their exposure to Christianity would have come only around the year 1000 when Hungary's rulers invited missionaries mainly from the German world to convert the descendants of the nomads who conquered the Carpathian Basin a century earlier. In that case words describing organized religious life in the Hungarian language would have been Germanic and not Slavic (Makkay 1994, 160-162).

In his book Makkay also took issue with the relative numbers of the conquerors and the autochthonous population of the Carpathian Basin at the time of the conquest of 895 . He suggested that the size of the conquering population of Prince Árpád's warriors was much smaller than the majority of historians in Hungary estimated, and he cited the similar opinions of several prominent Hungarian scholars. Finally Makkay turned to the issue of the origins of the Magyar-speaking Székely populations of Transylvania. In this connection he rejected all claims that these peoples might have been Turkic-speaking and he suggested that some of them, especially the peoples of the region in the heart of the Transylvanian Basin known as Mezóség, had probably settled there even before the rest of the Hungarians of Transylvania arrived during Avar times. Makkay's evidence for this interpretation of the Székely past is the archaic dialect of Hungarian spoken in that region (Makkay 1994, 153). ${ }^{6}$

\section{Other Critics of the Orthodox Theory of Hungarian Ethnogenesis}

Even before the arguments advanced by László and Makkay were largely forgotten in Hungary, other members of the Hungarian academic establishment came along to question the old theories of the Hungarian conquest and the origins of the Hungarians. The four outstanding figures of this new attack on orthodoxy were physical anthropologist Pál Lipták, archaeologists Dezső Simonyi and Gábor Vékony, and historian Péter Király.

Lipták was born a year after Ármin Vámbéry died. Through the study of the anatomy of the occupants of conquest-era graves, Lipták came to the conclusion that the majority of the people who entered the Carpathian Basin at the end of the ninth century were anatomically

\footnotetext{
${ }^{6}$ Other Székely populations in Transylvania were re-settled there from the Carpathian Basin's western frontiers by Hungary's early Árpádian kings, thereby contributing to the rich assortment of Hungarian dialects in the region.

A few years ago Makkay completed a revised and expanded edition of his book, but had problems finding a publisher for it. This situation is both ironic and regrettable. Authors who come up with outlandish theories of Hungarian pre-history have no trouble finding publishers (though not presses connected with Hungary's academic establishment) while a serious and knowledgeable scholar such as Makkay is left out in the cold. My information about his revised book comes directly from him.
} 
Dreisziger, Nándor. "Ármin Vámbéry (1832-1913) as a Historian of Early Hungarian Settlement in the Carpathian Basin." Hungarian Cultural Studies. e-Journal of the American Hungarian Educators Association, Volume 6 (2013): http://ahea.pitt.edu DOI: 10.5195/ahea.2013.110

different from the people who lived there at the time, and also from the people who live there at the present. That is, the majority of the conquerors were probably not Hungarians. The real ancestors of the Hungarians, Lipták suggested, settled in the Carpathian Basin in several waves, from the early fifth century on to the end of the ninth century, but especially during Avar times. It should be mentioned here that Lipták based these conclusions in part on the findings of the Hungarian archaeologist Dezső Simonyi. In his various publications Simonyi had argued that speakers of a proto-Hungarian language settled in the Carpathian Basin, along with Turkicspeaking proto-Bulgars, in the second half of the fifth century (Lipták 1975; Lipták 1980; Lipták 1983, 160-162; Simonyi 1981, 71-88). ${ }^{7}$

Another critic of the dominant theory of the "Hungarian conquest" was Gábor Vékony. A younger man than any of the scholars mentioned so far-he was born in 1944-Vékony spent most of his career teaching at Eötvös Loránd University in Budapest. Through his researches and teachings at Hungary's premier university, Vékony came to the conclusion that the ancestors of Hungarians didn't come to the Carpathian Basin at the end of the ninth century but most likely in the second half of the seventh, or possibly as early as the fifth. Vékony also believed that the nomadic tribes that conquered the Carpathian Basin at the end of the ninth century were not Hungarian - exactly as Vámbéry had argued a century earlier. Vékony agreed with Vámbéry when he maintained that the conquerors spoke Turkic dialects which they lost when they were assimilated by the masses of Hungarians they found living in this part of Central Europe (Vékony 2002).

A few years after the appearance of Vékony's monograph, another book surfaced in Hungary that questioned the traditional interpretation of the story of Hungarian ethnogenesis. The book was by Péter Király, another veteran member of Hungary's academic establishment. Király's arguments against the traditional interpretation of the "Hungarian conquest" were based not so much on the evidence of archaeology and anthropology but on Central European medieval written sources. After studying the latter for nearly seven decades, Király came to the conclusion that the ancestors of the Hungarians probably started to settle in the Carpathian Basin at the end of the sixth century. As evidence, Király cited pre-895 documents found in monasteries in what are now Germany, France, Austria and Switzerland. These documents contained references to a people called Ungar, Ungarus, Wenger, Hungarius, etc. living in the Carpathian Basin. Furthermore Király found references to migrants called by these names living in or near western and central European monastic centres, suggesting that individual Hungarians from the Carpathian Basin had migrated west and settled there. Király even found a reference to a "brother Hungariuß" in the registry book of the Benedictine monastery of Weissembourg (Weissenburg) in what is now eastern France (Király 2006, 214). The document that contains the name of Hungariuß is known to other historians as well (Haubrichs 1970, appendix 4). ${ }^{8}$

\footnotetext{
${ }^{7}$ In his 1980 essay Lipták concludes: "The process of becoming a people was completed for the Hungarians in the Carpathian basin.... [and] can be divided into two parts: 1. The period between the sixth and ninth centuries,..." (pp. 366f).

${ }^{8} \mathrm{I}$ had not been able to find a mention of Hungariuß' name in other contemporary Weissenburg documents.
} 
Dreisziger, Nándor. "Ármin Vámbéry (1832-1913) as a Historian of Early Hungarian Settlement in the Carpathian Basin." Hungarian Cultural Studies. e-Journal of the American Hungarian Educators Association, Volume 6 (2013): http://ahea.pitt.edu DOI: 10.5195/ahea.2013.110

The arguments of Lipták, Simonyi, Vékony, and Király were based on the findings of traditional disciplines. By the time they published the last of their books, another discipline useful for the study of the past had emerged: genomics, the study of y-chromosomal and mitochondrial DNA. In the next section of our study we'll examine what are the implications of recent genetic studies for Vámbéry's theories regarding Hungarian ethnogenesis.

\section{The Contribution of Genetic Research to the Knowledge of Hungarian Origins}

Early genetic studies were based on the examination of autosomal DNA and did not result in much more accurate knowledge of the past of human populations. About a decade ago, however, a great leap forward took place in the science of genetics when the first SNP (single nucleotide polymorphism) was discovered in the y-chromosomal DNA of men. Unlike autosomal DNA, y-chromosomal DNA does not re-combine completely through the process of conception. This means that its SNPs are passed on from father to son unchanged sometimes for hundreds of generations. About the same time it also became evident that markers in the mitochondria of human cells do the same thing and provide an effective means of tracing maternal lineages, since women pass these markers on to their children but men don't.

Soon genomic studies were undertaken in Hungary and focused on the DNA of conquestage populations as well as present day populations in Hungary and the Székelyland. They were conducted under the direction of geneticist István Raskó of the University of Szeged. Raskó's team studied mitochondrial and y-chromosomal DNA extracted from the skeletal remains of men and women - both members of the elite and commoners - and DNA samples taken from presentday Hungarians (Dreisziger 2011).

The first of these investigations examined the mitochondrial-DNA of three groups: conquest-era elite women (the wives and daughters of the conquerors), conquest-era women of commoner status, and present-day women in Hungary and the Székelyland. Raskó and his associates found that the DNA of conquest era elite women and that of conquest-era women of commoner status differed considerably. They also found that the mitochondrial DNA (mt-DNA) of conquest era elite women differed considerably from that of women living today in Hungary and the Székelyland. They learned however, that the mt-DNA of the conquest-era commoner women and that of today's women in Hungary and the Székelyland were similar. The conclusion from all this can only be that the conquerors were genetically not related to their subject peoples, and that Hungarian women of today are descendants not of the conquerors but of the subject peoples of tenth century Hungary, presumably of the population that had lived in the Carpathian Basin before the so-called "Hungarian" conquest (Tömöry et al. 2007).

In the Raskó team's second study, the y-DNA of men was examined. Two groups were studied: the conquerors on the one hand and present-day Magyar and Székely men on the other. The results of this investigation were again quite startling: the y-DNA of the two groups was different, signifying that the political-military elite of the population that conquered the Carpa- 
Dreisziger, Nándor. "Ármin Vámbéry (1832-1913) as a Historian of Early Hungarian Settlement in the Carpathian Basin." Hungarian Cultural Studies. e-Journal of the American Hungarian Educators Association, Volume 6 (2013): http://ahea.pitt.edu DOI: 10.5195/ahea.2013.110

thian Basin and present-day Hungarian men were genetically not related. To put this in another way: the population of today's Hungary and the Székelyland did not descend from Árpád's people (Csányi et al. 2008). ${ }^{9}$

In their third study Raskó's team looked for the genetic marker that identifies people with adult-onset lactose intolerance. In this project three groups were studied: 1) the ancient conquerors (and their immediate descendants); 2) ancient commoners (the subject peoples of the conquerors); and 3) present-day Hungarians (in Hungary and the Székelyland). From their investi-gations the members of Raskó's team concluded that all the adult conquerors suffered from lactose intolerance. At the same time the team found that, in the ratio of people with lactose intolerance to those without, there was no significant difference "between present-day Hungarian speaking populations and ancient Hungarian commoners" (Nagy et al. 2011; Raskó 2013). ${ }^{10}$

The conclusion from this third study can only be the same as that which resulted from the first two: the conquerors and their subject peoples were members of two distinct ethnic groups. More importantly these investigations suggest that the vast majority of present-day Hungarians cannot be the descendants of the conquerors: today's Hungarians are predominantly the progeny of the subject peoples of the tenth century, that is, of the pre-conquest population of the Carpathian Basin. To put it in another way, the conquerors left virtually no genetic footprints in the Hungarian population of subsequent times. Why? Because they were not numerous. As István Raskó remarked in a book he recently published on the subject: "the contribution of the conquerors to the genetic pool of present-day Hungarians [was] insignificant”(Raskó 2010, 158). Despite this statement, Raskó assumed that the conquerors spoke Hungarian and claimed that the pre-985 population of the Carpathian Basin "adopted [átvette]" their language. This of course is inconceivable; this is not how human evolution worked in the early Middle Ages (when there were no schools and just about every person was illiterate). In those times all nomadic warrior tribes who conquered a region populated by settled peoples invariably became assimilated by the local, autochthonous populations. That is, it was not the subject populations that "adopted" the language of the conquerors but the conquerors, i.e. their descendants, who learned the language of the subject populations. There appear to be no exceptions to this rule despite the fact that some people claim that the arrival of the English language in England at the time of the so-called "Anglo-Saxon conquest" was similar to what happened in the Carpathian Basin when Prince Árpád's warriors arrived there and forced their language on the local population. But, according to recent British scholarship, an Anglo-Saxon conquest of England had never taken place. What took place instead was migration by speakers of a West-Germanic language to what is now

\footnotetext{
${ }^{9}$ Members of the N1c1 y-chromosomal haplogroup were common among the conquerors- to date, not one of these men has been found among the male population of Hungary (but a small handful of them have been found among the Székelys). The usefulness of this study is called into question by the minuscule sample-pool Ráskó and his team worked with as far as the conquest-age population was concerned.

${ }^{10}$ The study also found that, as far as the incidence of lactose intolerance is concerned, the subject peoples of the 10th century Carpathian Basin and today's Hungarians show little difference from neighboring Central European populations.
} 
Dreisziger, Nándor. "Ármin Vámbéry (1832-1913) as a Historian of Early Hungarian Settlement in the Carpathian Basin." Hungarian Cultural Studies. e-Journal of the American Hungarian Educators Association, Volume 6 (2013): http://ahea.pitt.edu DOI: 10.5195/ahea.2013.110

England over many generations resulting in a proto-English language replacing various Celtic tongues as the dominant language of the region (Heather 2010, 12-21; Oppenheimer 2007, 47782; Pryor 2004). ${ }^{11}$

\section{Vámbéry's Conclusions: Contradicted or Confirmed?}

There can be no doubt that Vámbéry's book At the Cradle of Hungarians has some shortcomings. Its prose is often awkward and the composition is meandering and repetitious. We can suspect, however, that had Vámbéry lived a year or two longer, he would have eliminated most of these problems while he prepared the volume for publication. Of course, it is not too difficult to see some other problems with this extraordinary work.

Most criticism that his detractors directed at Vámbéry while he was still alive, and also after his death, concerned his claim that Hungarian was much more of a Turkic than an Ugric language. It would be unfair to focus too much on this issue today especially in view of the fact that by the time of his approaching old age Vámbéry had retreated from his earlier stance and admitted that the contribution made by the Hungarians' Ugric ancestors to modern-day Hungarian was real. The "kernel of the Magyar language was Ugric," he proclaimed more than once in his 1914 book. Still, his unbounded enthusiasm for the Turkic nature of the Hungarian language never abated completely.

While the question of the basic nature of the Hungarian language might best be left to linguists, some of Vámbéry's comments on conditions in the Carpathian Basin in the second half of the first millennium might warrant more nuanced interpretations. Of the many assertions Vámbéry made, the one that can be questioned first in the light of information that has become available in the hundred years since his time is the claim that, in early medieval times, the Carpathian Basin was sparsely populated. Only recently the Hungarian archaeologist Erzsébet Fóthi made the remark, based on her and her colleagues' decades-long researches of Avar-age burial sites in Hungary, that during Avar rule in the Carpathian Basin, there had been a veritable "population explosion" [valóságos népességrobbanás] (Fóthi 2013). And Teréz Olajos of the University of Szeged, another Hungarian expert on the age, convincingly argued that this Avarage population had survived into the tenth century, despite the wars the Franks had fought for the control of the region's Western half and the Bulgars for its eastern half (Olajos 2001, 50-56). In fact, some of Vámbéry's arguments support_as well as help explain—Professors Fóthy's and Olajos's claims regarding the relatively high population density in the Carpathian Basin in these times. In his 1914 book, Vámbéry talked of the "repeated" and almost "incessant" arrival of tribes and tribal fragments of the Hungarians' ancestors in the Carpathian Basin in Avar times. In doing this Vámbéry anticipated those English scholars who recently have questioned the story of the "Anglo-Saxon conquest" of England and replaced that age-old myth with the idea of the prolonged migration of the English-speakers into their new homeland during post-Roman, Roman, and even probably pre-Roman times. According to these scholars, in pre-modern

\footnotetext{
${ }^{11}$ On this subject see also the entry "Anglo-Saxon settlement of Britain" in Wikipedia http://en.wikipedia.org/wiki/Anglo-Saxon_settlement_of_Britain. Note that there is no mention in this entry of an "Anglo-Saxon conquest".
} 
Dreisziger, Nándor. "Ármin Vámbéry (1832-1913) as a Historian of Early Hungarian Settlement in the Carpathian Basin." Hungarian Cultural Studies. e-Journal of the American Hungarian Educators Association, Volume 6 (2013): http://ahea.pitt.edu DOI: 10.5195/ahea.2013.110

times - before there were schools and public literacy — culture change (including language change) happened only as the result of gradual transfer of knowledge and/or the migrations of peoples over a protracted period.

Another claim of Vámbéry's that can be questioned is the suggestion that the assimilation of Árpád's people by the locals took place in a short time. The experiences of other nations indicate that such assimilations often required much time. The abandonment by England's Norman conquerors of their French language took many generations, and the same seems to have been the case in the Lower Danube Valley where, among the region's Bulgar-Turkic elite, the Turkic language persisted for centuries after the regions' conquest by these people. In the case of the conquest of the Carpathian Basin by Prince Árpád's warriors, there appears to be evidence to the effect that the Turkic language of the conquerors persisted in some parts of Hungary, such as the Great Hungarian Plain, well into the twelfth century, probably even the 13th (Abu Hamid 1953, 65; Abu Hamid 1986, 56). ${ }^{12}$

Undoubtedly many other deficiencies of Vámbéry’s 1914 book could be mentioned. In fact, there can be no doubt that if someone published a book such as his nowadays, the defenders of historical orthodoxy in Hungary would declare it to be the work of a dilettante. But, rather than being the brainchild of a poorly-informed dabbler in proto-history, Vámbéry's book is a work full of unusual insights. It might best be seen not so much a summation of existing knowledge about Hungarian origins but a series of bold predictions as to what future research might uncover. As we have seen many of these predictions have stood the test of time and have been reiterated by highly qualified academics.

One observation Vámbéry made that no one nowadays could dispute was his claim that Hungarians have a very mixed ancestry. Today we know that Hungarian men, for example, belong to more than a dozen different y-chromosomal haplogroups that are genetically very distant from each other. In the case of Hungarians, however, it is not only that the major genomic groups they belong to are distant from each other, but also that, within each of these major groups, the sub-groups to which Hungarians belong are similarly quite distant from each other. As far as their genetic background is concerned, Hungarians are indeed one of the most diverse peoples of the world. ${ }^{13}$

By far the most important element of Vámbéry's theory of Hungarian ethnogenesis is his argument that the people who conquered the Carpathian Basin at the end of the ninth century were a different people ethnically. If these conquerors were not Hungarians but Turks, then the ancestors of the Hungarians must have lived in the Middle Danube Valley before 895 since we know that no tribes or tribal fragments speaking the Hungarian language had come to the Carpathian Basin in subsequent centuries. As we have seen above, this particular element of Vámbéry's theory has been endorsed by most of the scholars that have been mentioned in this

\footnotetext{
${ }^{12}$ Undoubtedly Abu Hamid, who for years had lived among Turkic-speakers in the southern Ural region, knew Turkic languages and probably conversed with the Bashkir of the Great Hungarian Plain in their own language.

${ }^{13}$ Information from Tibor Fehér, manager of the "Hungarian project" of the DNA testing company FamilytreeDNA of Texas.
} 
Dreisziger, Nándor. "Ármin Vámbéry (1832-1913) as a Historian of Early Hungarian Settlement in the Carpathian Basin." Hungarian Cultural Studies. e-Journal of the American Hungarian Educators Association, Volume 6 (2013): http://ahea.pitt.edu DOI: 10.5195/ahea.2013.110

study. Lajos Kiss of Marjalak acknowledged it. Though this is little known in Hungary, both Gyula László and János Makkay also subscribed to this interpretation of Hungarian ethnogenesis by the early- to mid-1990s when they came up with an amended version of their "Dual Conquest" theory. As we have seen Dezső Simonyi dated the arrival of the Hungarians to the early fifth century, while Pál Lipták felt that most of them had arrived during Avar times. Gábor Vékony was not sure when they arrived in the Carpathian Basin: in the 670s or possibly as early as the time of Attila the Hun; and Péter Király gave the year 590 as the approximate date of their arrival. Most of these people, furthermore, had also argued that the conquerors of the late ninth century were Turks. Vékony went so far as saying that they might have been Bashkirs, a people of Turkic-speakers. And all these scholars had disputed the high numbers (in the hundreds of thousands) that most defenders of historical orthodoxy usually give for the conquerors. Vékony suggested that when the conquerors settled in the Carpathian Basin they constituted about "one percent" of the population there (Vékony 2002, 219) — he did not say so, but that would have put their number at about 20,000. As we have seen, Vámbéry gave an even lower estimate. ${ }^{14}$

We may ask what proof there is for this claim of Vámbéry and the other critics of the orthodox theory that the conquerors of 895 fame were not Hungarians, but members of a different ethnic group. The written evidence in this connection is limited. In Byzantine documents the conquerors are always referred to as Turks, and their land as Turkia. Some critics of the orthodox theory of Hungarian ethnogenesis point out that most of the conquerors' tribal names as well as the names of their leaders were undoubtedly Turkic. The fact that the conquerors buried their dead in very peculiar manner, and included distinctive grave-goods with them, also suggests that they constituted an ethnic group that was different from the autochthonous population of the Carpathian Basin (Szentpétery 2013).

Additional evidence supporting the idea that the conquerors were different ethnically from the population they subjugated comes from scientific research. As we have seen recent genetic studies also underscore this point of view. The mitochondrial DNA of the women among Árpád's people differed from the mt-DNA of tenth century subject peoples, as well as from the mt-DNA of later Hungarian populations. The geneticists who examined the y-DNA of conquestera men came to the same conclusions regarding them: as far as their $y$-DNA was concerned, the conquerors differed substantially from their subject population-as well as from later Hungarian populations. The geneticists also established that lactose intolerance was present in all adult conqueror individuals whose DNA is known to science, while lactose intolerance in the subject population - as well as in today's Hungarian population - is not substantially different from that respectively of early Medieval and present-day European populations.

Some defenders of the orthodox theory of Hungarian ethnogenesis have suggested that the conquest of the Carpathian Basin was carried out by a people composed of two different ethnic elements: an elite that was Turkic while their subjects were Ugric, i.e. Hungarian speaking. To these historians this situation would explain the differences between the genetic

\footnotetext{
${ }^{14}$ Some historians might ask the question how a small army could conquer a large, fairly densely populated region of the continent; however, the history of medieval Europe offers numerous examples for such conquests by warrior peoples. Prince Árpád's Turks were fierce, highly experienced warriors, equipped with superior weapons, as well as with top-notch means of transportation: their horses were unmatched in skill and endurance in Europe.
} 
Dreisziger, Nándor. "Ármin Vámbéry (1832-1913) as a Historian of Early Hungarian Settlement in the Carpathian Basin." Hungarian Cultural Studies. e-Journal of the American Hungarian Educators Association, Volume 6 (2013): http://ahea.pitt.edu DOI: 10.5195/ahea.2013.110

make-up of the classical conquerors and the subject peoples of tenth century Hungary. The problem is that there is very little evidence that would support the idea that the conquerors of 895 were made up of two substantially different ethnic groups: one mainly with Asian DNA and the other predominantly with European genetic characteristics. A few defenders of the orthodox view suggest that the conquerors were made up a nomadic elite and an agriculturalist sub-class, but the coexistence of nomads and agriculturalists in one political entity, a tribal federation, is highly unlikely. Furthermore, the conquerors had been almost constantly on the move from the distant east for at least two generations before they entered the Carpathian Basin (Türk, 2011); the existence of a large or even a moderate sized agricultural population in their society during this time is next to inconceivable. Still further evidence against the argument that the conquerors were made up of the members of two different peoples comes from physical anthropologists. One of these is Erzsébet Fóthi who, after studying tenth century skeletal remains for several decades, came to the conclusion that the conquerors constituted a single people rather than one in which the elite was ethnically different from the rest of the population. This brings us to the most important evidence that can be brought up in favor of the argument that the conquerors who arrived in the Carpathian Basin at the end of the ninth century were ethnically different from Hungarians then - and later. This evidence is provided by the results of anthropological research.

One physical anthropologist who called attention to the fact that the anatomical features of the conquerors were not the same as those of the population-at-large of tenth century Hungary was the above-mentioned Pál Lipták. We may recall his conclusion that the elite of the tenth century population of the Carpathian Basin was "characterized by a significant ethnic component of Turkic... origin..." (Lipták 1983, 30, 160). ${ }^{15}$ Lipták's views have been echoed recently by Erzsébet Fóthi. She has been studying the anatomical features of people resting in fifth to eleventh century graves of the Carpathian Basin for most of her long carrier as a physical anthropologist. In regard to the conquerors she came to the conclusion that, judging by their anatomical features, they were not only one people, but they were very different from the peoples that populated the Carpathian Basin at the time. She added that as far as a people with similar anatomical features were concerned, the conquerors most resembled the Turkic-speaking Bulgars who had conquered the Lower Danube Valley only a few centuries earlier. They were not the same people, Fóthi argued, but came from the same genetic stock, and their former homeland had been the southern Urals region of today's European Russia (Fóthi 2013).

Fóthi and her colleagues also studied other pre-twelfth and thirteenth century populations in the Carpathian Basin. Among those who they examined extensively were the ancestors of the Székelys of the Háromszék district in the south-easternmost part of Transylvania. It should be mentioned here that in the early Árpádian Age the Székelys were generally used as the Hungarian Kingdom's border-guards, and at one point in time some of them were transferred from the north-western frontier to the south-eastern frontier. According to Fóthi the medieval population of the Háromszék region was anatomically the same as the population of the northwesternmost part of the Carpathian Basin had been in earlier times, long before the end of the

\footnotetext{
${ }^{15}$ Lipták goes on to explain the archaeological and anatomical differences between occupants of graves in postconquest Hungary, of the conquerors and the common people, the latter of which he deems to be "ethnically Hungarian.” (Lipták 1983, 160-161).
} 
Dreisziger, Nándor. "Ármin Vámbéry (1832-1913) as a Historian of Early Hungarian Settlement in the Carpathian Basin." Hungarian Cultural Studies. e-Journal of the American Hungarian Educators Association, Volume 6 (2013): http://ahea.pitt.edu DOI: 10.5195/ahea.2013.110

ninth century. The Háromszék population also showed remarkable similarity to the population that had lived in the Zala River Valley of the Carpathian Basin's western part during Avar and Carolingian (Frankish) times. According to Fóthi, the medieval inhabitants of Háromszék were somewhat different in their anatomical features from other Székely peoples such as those of Udvarhely, Csík- and Gyergyószék, and also from other peoples of the pre-Conquest Carpathian Basin, but they did not constitute a separate ethnic group within the general Hungarian population of the age.

What Fóthi observed about the early anatomical development of Háromszék's postconquest era population is highly reminiscent of Vámbéry's theory of the genesis of the Hungarian ancestors' language. It may be recalled that Vámbéry said that the language of the Hungarians developed during the centuries before 895 from the blending of Ugric and eastern Turkic linguistic elements, producing the language that the ancestors of the Hungarians spoke in the Carpathian Basin by the end of the ninth century. Fóthi's conclusions about the anatomical development of the population that at one point occupied the north-westernmost region and later also the south-easternmost districts of the Carpathian Basin are remarkably similar. "The development of this people," she wrote, "must have taken place" in a region where long before the twelfth century there lived a population - the predominant majority of whom had long skulls typical of Europeans - together with another people, much smaller in numbers, of Asian origin. The sporadic appearance of anatomical features in the resulting population characteristic of Mongoloids is explainable by the blending of these two human types throughout the "generations" or even perhaps the "centuries" that had preceded the re-settlement of the Székelys of Háromszék in their present (Transylvanian) homeland (Fóthi et al. 2012, 506, 543-552). According to Vámbéry and Fóthi then, the development of the Hungarians' language and the evolution of their physical anatomy paralleled each other, and took place in the Carpathian Basin long before the arrival of Prince Árpád and his Turkic-speaking warriors.

A century after Vámbéry had written his last book on Hungarian ethnogenesis, the foremost elements of his theory appear to be on their way to being confirmed by the researches that have been conducted since 1913 by several eminent Hungarian scholars and scientists. Evidently not all issues have been settled. The complex story of Hungarian origins has not revealed all its secrets and much more research needs to be done for scholarship to come to a clearer, more convincing picture of the distant Magyar past. More archaeological and anthropological research needs to be done and more DNA samples will have to be extracted from ancient bones - just to mention a few of the fields in which further inquiry and reflection is needed. Will the researches of the next 100 years continue to confirm Armin Vámbéry's bold predictions regarding Hungarian ethnogenesis? The writer of these lines suspects that they will.

\section{Works cited}

Abu Hamid al-Garnati (1953). Abu Hamid el Granadino y su relacion de viaje por tierras eurasiaticas. tr. from the Arabic by Cesar Emil Dubler. Madrid: Impr. y Editorial Maestre. (1985). Abu-Hámid Al-Garnáti utazása Kelet-és Közép-Europában, 1131-1153 [The travels of Abu-Hamid al-Garnati in eastern and central Euorpe, 1131-1153] ed. O.G. Bolsakov and A.L. Mongajt, tr. Tamás Iványi and György Bakcsi. Budapest: Gondolat. 
Dreisziger, Nándor. "Ármin Vámbéry (1832-1913) as a Historian of Early Hungarian Settlement in the Carpathian Basin." Hungarian Cultural Studies. e-Journal of the American Hungarian Educators Association, Volume 6 (2013): http://ahea.pitt.edu DOI: 10.5195/ahea.2013.110

Csányi, Bernadett, Erika Bogácsi-Szabó, Gyönyvér Tömöry, Ágnes Czibula, Katalin Priskin, Aranka Csősz, B. Mende, P. Langó, K. Csete, A. Zsolnai, E. K. Conant, C. S. Downes and István Raskó (2008). "YChromosome Analysis of Ancient Hungarian and Two Modern Hungarian-Speaking Populations from the Carpathian Basin." Annals of Human Genetics 72: 519-534.

Dreisziger, Nándor (2011). “Genetic Research and Hungarian 'Deep Ancestry'," AHEA E-journal, vol. 4.

Fóthi, Erzsébet, Zsolt Berner, Tamás Hajdu and Ivett Kővári (2012). "Középkori embertani leletek a Székelyföldön" [Medieval anthropological specimens in Székelyland] in A középkori Székelyföld [The Székelyland of the Middle Ages] author and editor Elek Benkő, 473-552. Budapest: MTA Bölcsészettudomáyi Kutatóközpont Régészeti Intézet.

Fóthi, Erzsébet (2013a), “A Kárpát-medence 6-11. századi történetének embertani vonatkozásai” [The anthropological aspects of the history of the Carpathian Basin in the $6^{\text {th }}$ to $11^{\text {th }}$ centuries], a paper given at a conference on Hungarian Proto-history, sponsored by the Hungarian Academy of Sciences in Budapest, 17 April 2013. http://www.btk.mta.hu/magyar-ostorteneti-temacsoport-hu/tudomany-eshagyomanyorzes-konferencia.htm

- (2013b). Interview published in the online version of National Geographic, "Szenzációs kutatási eredmények a honfoglaló magyarokról" [Sensational research results about the conquering Hungarians], http://www.szabir.com/blog/honfoglalo-magyarok accessed 20 April 2013.

Haubrichs, Wolfgang (1970). “Dei Weißenburger Mönchslisten der Karolingerzeit,” Zeitschrift der Geschichte des Oberrheins, 118, NF 79 (1970): 1-42.

Heather, Peter (2010). Empires and Barbarians: The Fall of Rome and the Birth of Europe. Oxford: Oxford University Press.

Király, Péter (2006). A honalapítás vitás eseményei: A kalandozások és a honfoglalás éve [The disputed events of the establishment of a homeland: The marauding expeditions and the year of the conquest] (Nyíregyáza: Nyíregyházi Főiskola.

Kocsis, Károly (2013). Speech in memory of Vámbéry at a plaque dedication in Dunaszerdahely on 23 March 2013; http://www.foldrajzitarsasag.hu/33-cikkek/hirek/69-kocsis-karoly-unnepi-beszede

László, Gyula (1978). A „,kettôs honfoglalás” [The “Dual Conquest”] Budapest: Magvetö. . "Életem egyik fele, a régészet" [One half of my life, archaeology] MMA Akadémiai beszélgetések, 17 April 1997, http://www.mmakademia.hu/ab/3/303.php (accessed 13/12/2010)

Lipták, Pál (1975) “A finnugor népek antropologiája,” in Uráli népek: nyelvrokonaink kultúrája és hagyományai, ed. Péter Hajdú. 129-137. Budapest: Corvina.

(1980). "Physical Anthropology of the Finno-Ugric Peoples," in Physical Anthropology of European Populations, ed. Ilse Schwidetzky, B. Chiarelli and Olga Necrasov. 365-368. The Hague, Paris, New York: Mouton Publishers.

(1983). Avars and Ancient Hungarians. Budapest: Akadémiai Kiadó.

Makkay, János (1993). “Embertannal kapcsolatos adatok a 'kettős honfoglalás' vitájához” [Anthropological data concerning the debate about the 'dual conquest']. Anthropologiai Közlemények, 35: 213-219.

(1994). A magyarság keltezése [The dating of Hungarians]. Szolnok: Jász-Nagykun-Szolnok Museums; $2^{\text {nd }}$ revised and expanded edition.

Mandler, David (2011). "Vámbéry, Victorian Culture, and Stoker's Dracula," in Comparative Hungarian Cultural Studies, ed. Steven Tötösy de Zepetnek and Louise O. Vasvári, 47-58. West Lafayette, Indiana: Purdue University Press.

Marjalaki Kiss, Lajos (1930). “Új úton a magyar őshaza felé: Anonymus nyomdokain” [On a new path to the Hungarian ancient homeland: in the footsteps of Anonymus]. Nyugat 1930, no. 12; available online at: http://epa.oszk.hu/00000/00022/00492/15257.htm 
Dreisziger, Nándor. “Ármin Vámbéry (1832-1913) as a Historian of Early Hungarian Settlement in the Carpathian Basin." Hungarian Cultural Studies. e-Journal of the American Hungarian Educators Association, Volume 6 (2013): http://ahea.pitt.edu DOI: 10.5195/ahea.2013.110

. (1956). "Gondolatok a Magyar nép eredetéröl" [Thoughts about the origins of the Hungarian people]. Borsodi Szemle, I évf. 1-2 sz. 68-80, 81-103.

Nagy, Dóra, Gyöngyvér Tömöry, Bernadett Csanyi, Erika Bogácsi-Szabó, Ágnes Czibula, Katalin Priskin, Olga Bede, László Bartosiewicz, C. Stephen Downes, and István Raskó (2011). "Comaprison of Lactose Persistence Polymorphism in Ancient and Present-Day Hungarian Populations.” American Journal of Physical Anthropology 138.

Olajos, Teréz (2001). “Az avar továbbélés kérdéséröl” [About the question of the Avar population's survival]. Tiszatáj (November): 50-56, http://www.lib.jgytf.u-szeged.hu/folyoiratok/tiszataj/01-11/olajos.pdf .

Oppenheimer, Stephen (2007). The Origins of the British. London: Robinson.

Pryor, Francis (2004). Britain AD: A Quest for Arthur, England and the Anglo-Saxons. London: Harper and Collins.

Raskó, István (2010). Honfoglaló gének [Conquering genes] Budapest: Medicina Könyvkiadó. (2013). "Genetikai múltba nézés, egy magyar torzó tanulságai” [A genetic glance into the past: the testimony of a Hungarian torso] a paper given at a conference on Hungarian Proto-history, sponsored by the Hungarian Academy of Sciences in Budapest, 17 April 2013. http://www.btk.mta.hu/magyarostorteneti-temacsoport-hu/tudomany-es-hagyomanyorzes-konferencia.htm

Simonyi, Dezső (1981). “A pannoniai bolgárok és a magyarság kialakulása” [The Bulgars of Pannonia and the ethnogenesis of Hungarians] in Tanulmányok a bolgár-magyar kapcsolatok köréböl a bolgár állam megalapításának 1300. évforulójára [Studies in the field of Bulgarian-Hungarian relations on the $1,300^{\text {th }}$ anniversary of the founding of the Bulgarian state], ed. Čavdar Dobrev, Péter Juhász and Petar Miâtev, 71-88. Budapest: Akadémiai Kiadó.

Szentpéteri, József (2013). "Kritikai megjegyzések az Avar-Magyar asszimiláció kérdéseihez” [Critical comments on the subject of Avar-Magyar assimilation] a brief paper given at a conference on Hungarian Proto-history, sponsored by the Hungarian Academy of Sciences in Budapest, 17 April 2013. http://www.btk.mta.hu/magyar-ostorteneti-temacsoport-hu/tudomany-es-hagyomanyorzeskonferencia.htm

Tömöry, Gyönyvér, Bernadett Csányi, Erika Bogácsi-Szabó, Tibor Kalmár, Ágnes Czibula, Aranka Csősz, Katalin Priskin, Balázs Mende, Péter Langó, C. Stephen Downes and István Raskó (2007). "Comparison of Maternal Lineage and Biogeographic Analyses of Ancient and Modern Hungarian Populations." American Journal of Physical Anthropology. 134: 354-368.

Türk, Attila Antal (2011). “A Magyar őstörténet és a szaltovói régészeti kulturkör” [Hungarian ancient history and the Saltovo culture]. A doctoral dissertation defended at the University of Szeged, 22 Nov. 2011.

Vámbéry, Ármin (1882). A magyarok eredete [The origin of Hungarians]. Budapest. (1895). A magyarság keletkezése és gyarapodása [The genesis and development of Hungarians]. Budapest: Franklin; republished in Dunaszerdahely, 2003; http://mek.oszk.hu/03000/03032/ .

(1914). A magyarság bölcsőjénél: A magyar-török rokonság kezdete és fejlödése [At the cradle of Hungarians: The beginning and development of the Magyar-Turkish relatedness]. Budapest: Athenaeum; http://mek.oszk.hu/06900/06996/06996/pdf .

Vékony, Gábor (2002). Magyar östörténet - Magyar honfoglalás [Hungarian prehistory - Hungarian conquest]. Budapest: Nap Kiadó. 
Dreisziger, Nándor. "Ármin Vámbéry (1832-1913) as a Historian of Early Hungarian Settlement in the Carpathian Basin." Hungarian Cultural Studies. e-Journal of the American Hungarian Educators Association, Volume 6 (2013): http://ahea.pitt.edu DOI: 10.5195/ahea.2013.110 